\title{
The Effects of Administrative Empowerment on Employees Job Satisfaction in Five-star Resorts in Hurghada City By
}

\author{
Mohamed S. Hassan ${ }^{1}$ ， Mohamed Omar Ahmed ${ }^{1}$, Seham Abo-talib ${ }^{2}$
}

\begin{abstract}
Administrative empowerment is a critical process for the employees, as it is a contemporary concept that leads the employee to achieve high levels of collaboration, teamwork, self-confidence, creativity, independent thinking and entrepreneurship. In general, the hotel managers play an important role in empowering their employees by giving them the information and responsibilities of the work, as well as, providing an atmosphere of trust between the management levels that help employees in decision-making. Additionally, administrative empowerment gives employees more flexibility and empowerment that help them to improve their performance and loyalty to the work. The study aims to identify the extent of the implementation of administrative empowerment of the employees in five-star resorts in Hurghada City, and its impact on job satisfaction. The study sample consists of employees of the five-star resorts in Hurghada City. This research is applied in 23 resorts of Hurghada City in Egypt. It adopts a quantitative approach for achieving its aims and desired objectives. A convenient sample was selected consisting of 500 hotel staff with an average of $72.4 \%$ response rate. A questionnaire is used for collecting data which is later analysed using SPSS version 24 . The results indicate that administrative empowerment and its dimensions have a positive effect on job satisfaction. According to the results, the study proves that there is a strong correlation between administrative empowerment and employee's satisfaction in the five-star resorts in Hurghada City. It also recommends that hotel resorts empower and strengthen their employees by trusting in them, giving them the authority to carry out their tasks without consulting the administration, encouraging teamwork and providing them with appropriate training programs as well as communication channels for contacting with senior management. This study contributes to identifying the concept of administrative empowerment, its importance and dimensions as well as enriching the studies on the relation between administrative empowerment and its impact on job satisfaction. However, there is a lack of studies that show the effect of administrative empowerment on job satisfaction in the resorts in Egypt, especially in Hurghada resorts.
\end{abstract}

1- Hotel Studies Department, Faculty of Tourism and Hotels, Fayoum University,

2- Tourism Studies Department, Higher Institute of Tourism and Hotels, King Mariout - Alexandria, Egypt. 


\section{The Effects of Administrative Empowerment on Employees Job Satisfaction in Five-star Resorts in Hurghada City}

Keywords Administrative empowerment, job satisfaction, resorts, Hurghada.

\section{Introduction}

The rapid development that is currently taking place in the resort environment necessitates change and transformation to win the competition (Ashton, 2018). Therefore, the survival and prosperity of tourist resorts depend largely on achieving more results than those achieved by competitors through increasing their effectiveness and integration into the competitive environment and coping with a world of change, which necessitate the fact that the institution has no choice but to change (Nassar, 2017).

As the business environment has changed and many variables have been introduced in all aspects, which have put a great pressure on both the employees and the institutions in which they work, the need for modern administrative methods has emerged (Bailey et al., 2018). Administrative empowerment is one of the modern and different administrative methods suitable for change processes in an environment. The administrative method is based on increasing the ability of the institution to develop itself continuously by paying attention to the development of its workers. Administration is empowered by adopting practices and methods that encourage the empowerment of employees as a representative of the authorities, and enhance the employees' creative and innovative abilities and self-reflection's skills (Bratton and Gold, 2017).

Recently, the concept of "administrative empowerment" plays an important role in the development of managerial thought as a result of the change of major global organizations from being authoritarian organizations that are known as "possible organization" and the subsequent transformation of multi-level organizational charts into small. In this context, the approach to empowering employees is closely linked to the prevailing development trends related to the development of the human aspect in the organization (Al-Kaabi, 2016). In this sense, administrative empowerment depends on a new philosophy, in which managers should focus on the employees. Additionally, the employees are considered the biggest threats to the success or failure of the organization. Accordingly, the relationship and cooperation between the managers and employees is the cornerstone of the successful adoption of development methods within the organization (Abualoush et al., 2018). 


\section{Significance of the study}

This study is important for its role in identifying the requirements of administrative empowerment of employees in resorts, which is seen as an effective step in the process of developing the performance of the employees and enabling them to participate effectively in the management decisionmaking. As a result, this helps in finding solutions adopted by resorts management to address weaknesses in administrative empowerment, and to make use of this topic by circulating it to other resorts in Egypt.

\section{Statement of the problem}

Administrative empowerment is one of the modern administrative methods that contribute to increasing the efficiency of resort hotels, which is based on increasing the practices of empowerment and development of employees (Nassar, 2017). Such practices indicated that the managerial systems adopted by resorts are very traditional and old. The five-star hotels system in Hurghada City is an old traditional administrative method that does not keep pace with the change and development in the field of human resources (Al-Tayeb, 2008). In this traditional system, the majority of decisions come from the senior management staff without reference to the lower administrative levels in the regulatory hierarchy. In addition, the employees do not have the opportunity to play more positive roles, due to the lack of authority and empowerment to do their job (Al-Kaabi, 2016), the weak ways of developing their creative aspects and the lack of freedom in taking action without reference to the higher administrative levels. All these factors may cause weak self-thinking and lack of creativity in performance, which will reduce the employees' participation. More broadly, the employees will not be able to handle responsibility or to have a strong affiliation to work (Bratton and Gold, 2017).

\section{The aim of the study}

The major aim of this research is to identify the extent of the implementation of administrative empowerment of the employees in five-star resort hotels in Hurghada City and its effect on job satisfaction. In order to reach this aim, there are five objectives identified:

1. To critically review relevant literature related to administrative empowerment and to develop a conceptual framework.

2. To identify to what extent administrative empowerment is implemented in five-star resorts in Hurghada City.

3. To highlight the role of administrative empowerment in improving job satisfaction in five-star resorts in Hurghada City. 
4. To identify the right steps for implementing administrative empowerment in five-star resorts in Hurghada City.

5. To explore the challenges of implementing administrative empowerment in five-star resorts in Hurghada City.

\section{Study hypotheses}

1. It hypothesizes that there are no significant differences of demographic variables of administrative empowerment of employees in five-star resort hotels in Hurghada City.

2. It hypothesizes that there are no statistically significant effects of administrative empowerment of employees on job satisfaction in fivestar resort hotels in Hurghada City.

\section{Literature review}

Today, business organizations are undergoing a fundamental and significant change in their strategies because of the significant change in economic activity and the emergence of new data such as globalization, increased complexity, technological change and increased competition (Abualoush et al., 2018). In order to improve the ability of organizations to adapt to these new variables and to respond to the requirements of this change, departments have been concerned with, among others, knowledge management and administrative empowerment, which depend on individual capacity, efficiency and the way in which they are handled by the administration, where there is a need for attention to capacity development, guidance, motivation, empowerment, grant of freedom, trust and ability to work without direct intervention from senior management (Ajlouni, 2013).

The study of Bailey et al. (2018) explained that administrative empowerment is considered one of the most important issues for developing the managerial thinking. It is considered as a distinctive characteristic of empowerment that seeks to develop the employees through increasing their abilities and skills to solve problems (Al-Tayeb, 2008). Administrative empowerment of employees is one of the weapons of contemporary organizations in order to face the challenges in marketplace, competition, globalization and quality in the work environment (Felemban, 2009). On the other hand, the employees satisfaction about the work environment play a critical role in improving productivity, performance and reducing employee turnover and work problems (Al-Dmour et al., 2018). 


\section{Administrative empowerment concept}

Administrative empowerment is based on the ability of senior management to give authority and trust to employees to perform their jobs and duties freely, which contributes to creating an atmosphere of satisfaction and a sense of importance and increased responsibility. This also creates a positive feeling among employees, which plays an important role in motivating them for doing their job (Al-Saadi, 2006). Therefore, Collings et al. (2018) argue that administrative empowerment is to empower the members of teamwork to perform their duties without any feelings of stress. Besides, it also motivates and assists the employees to improve their performance and reduce risks that appear during work. On the other hand, AlTayeb (2008) defines administrative empowerment as a modern strategy aimed at unlocking the potential of individuals in the organization as well as involving the employees in determining the organization's future vision because the organization's success largely depends on how people's needs are integrated with the organization's vision and goals.

Jalab and Al-Husseini (2013) mention that administrative empowerment is an administrative practice that contributes to strengthening the role of the individual in the organization through participating in the process of decision-making and all the processes required for the work which lead to a successful and effective performance. In addition, administrative empowerment is defined as the process that helps employees to participate in the processes of training, developing, planning and controlling of their job with a view to achieve a positive performance for the sake of carrying out the organizational objectives. Abdelbaki (2004) believes that administrative empowerment is to delegate all the powers and responsibilities to the employees and to give them a full freedom to perform work in their own way without a direct intervention from the administration, with the provision of the appropriate resources, the appropriate work environment and the rehabilitation of behavioral, technical and skill-related issues, to help them perform effectively, and to trust in them. However, there are differences between empowerment and delegation as shown in table (1). 


\section{The Effects of Administrative Empowerment on Employees Job Satisfaction in Five-star Resorts in Hurghada City}

Table (1): the differences between administrative empowerment and delegation

\begin{tabular}{|l|l|}
\hline \multicolumn{1}{|c|}{ Delegation } & \multicolumn{1}{c|}{ Empowerment } \\
\hline $\begin{array}{l}\text { Transfers part of the permissions' authority } \\
\text { to employees. }\end{array}$ & Allows employees to be able to decide. \\
\hline Delegation of authority in specific areas. & $\begin{array}{l}\text { Authority is used broadly by the employees } \\
\text { in different scopes. }\end{array}$ \\
\hline $\begin{array}{l}\text { Responsibility remains in the hand of the } \\
\text { authorized staff. }\end{array}$ & $\begin{array}{l}\text { Success is attributed to the employees who } \\
\text { take responsibility for their failures. }\end{array}$ \\
\hline Delegation is led by the employees. & Empowerment is attributed to self-leadership. \\
\hline $\begin{array}{l}\text { Part of information is made available to } \\
\text { employees }\end{array}$ & $\begin{array}{l}\text { Iinformation is distributed between the } \\
\text { management and employees. }\end{array}$ \\
\hline $\begin{array}{l}\text { Delegation may be temporarily canceled } \\
\text { or modified in scope or depth. }\end{array}$ & $\begin{array}{l}\text { Empowerment is a conviction and a strategic } \\
\text { choice. }\end{array}$ \\
\hline
\end{tabular}

\section{The importance of administrative empowerment}

Several studies (Burke et al., 2015; Kohli and Sharma, 2017; Kong et al., 2018) show that administrative empowerment has benefits for both resorts and employees as follows:

Firstly: for resorts, administrative empowerment provides high productivity, low absenteeism and turnover, improvement in the quality of production or services, and achievement of a privileged position, as well as increases competitiveness, cooperation in problem solving and high innovation capabilities.

Secondly: for employees, administrative empowerment plays an important role in satisfying the individual needs of self-esteem. It provides the employees with a high resistance to work pressure, a high loyalty and affiliation to their resort and a high degree of job satisfaction and responsibility.

\section{The objectives of administrative empowerment}

Many researches and studies have addressed the objectives of administrative empowerment of employees as follows (Kruja et al., 2016; McPhail et al., 2015):

1. It helps employees to contribute and participate in decision making.

2. It helps workers to solve problems they face without waiting for their superiors to resolve these problems.

3. It increases the quality of job performance of employees.

4. It overcomes the employees' feelings of job dissatisfaction

5. It reduces costs.

6. It reduces the rate of labor turnover.

7. It overcomes bureaucracy and career routines by creating functional integration of employees.

8. It helps employees to effectively take on the risks of their work. 


\section{Administrative empowerment dimensions Delegation of authority}

It is the method used to transfer specific powers to the employees with setting the framework within which each employee can work for facilitating the process of making operational decisions at the appropriate level. The mandate includes assigning tasks to the employees and giving them the necessary and required authority to practice these tasks with the willingness of subordinates to bear the consequences of responsibility for an acceptable performance of these tasks (Pelit et al., 2011). Al-Kaabi (2016) points out that it is intended to entrust responsibility and authority to another person to complete a clearly defined duty. He also states that the commander assigns some of his competencies derived from the law to a worker from successive administrative levels.

\section{Teamwork}

Jalab and Al-Husseini (2013) indicate that teamwork is a group of people forming a system of interconnected entities with a common goal. However, there is a clear difference between the working group and the community in terms of the comprehensiveness of work, since the team is tasked to accomplish the task by consulting and collaborating with colleagues and the officials for achieving the goal in general. In other words, the team work depends on the organizational structure and the collective responsibility for achieving the required and common goal teamwork, so the department is usually keen to encourage teamwork and to create the collective spirit for a successful teamwork (Lee et al., 2015).

\section{Training and development}

This refers to the efforts that provide the employees with the information and knowledge acquired through the performance of work or the development of the skills, knowledge and experience of the employees in order to increase their current and future efficiency (Namasivayam et al., 2014). Training is an ongoing process in the organization for developing the skills of its employees. In order to improve the quality of services and to achieve the satisfaction of the users, the organization depends on providing its employees with all the means of learning through training, experimentation, group learning and knowledge management (Rahim, 2017). Training is also linked to administrative empowerment when the training process is geared towards enhancing individual confidence and developing the employee's capacity and skills for making decisions and taking 


\section{The Effects of Administrative Empowerment on Employees Job Satisfaction in Five-star Resorts in Hurghada City}

responsibility for the outcome of their decisions and actions (Lee et al., 2015).

\section{Motivation}

It is known that incentives have an active role in strengthening relationships between the organization and its employees and hence achieving the organizational goals. These incentives may be physical or moral, individual or collective. The incentives' impact depends on how far they motivate individuals and enhance their enthusiasm, trust and loyalty to the organization (Tsaur et al., 2004). The organization should increase the productivity and efficiency of its employees through motivating and developing the employees' needs. Consequently, the organization provides the employees with objective incentives and salaries suitable for the efforts they exert in the work. The motivation system should depend on the employee's efficiency in accomplishing the desired tasks. In this sense, the basis of empowerment is a positive reinforcement (Zahid et al., 2017).

\section{Organizational structure and effective communication}

The organizational structure is clearly seen in the distribution of powers and functions, and with empowerment, the scope of supervision becomes broad leading to a flat (horizontal) organizational structure, where administrative levels are limited and hence individuals can quickly communicate with decision-makers. But if the scope of the supervision is tight, it will lead to a longitudinal organizational structure (vertical) where administrative levels increase (Zahid et al., 2017).

\section{Administrative empowerment steps}

The resort management needs to apply administrative empowerment to overcome the obstacles and challenges that might be faced during its implementation. These stages are illustrated as below:

Phase one: starts with a redesign of the work to achieve professional enrichment, in which the skills of the employees appear in a limited and uncomplicated way which makes their level of empowerment low (Al-Saadi, 2006).

Phase two: encourages an employee to make suggestions for developing of their skills and broadening their field of empowerment compared to the previous stage (Abdelbaki, 2004).

Phase three: gives employees, who have abilities and skills, the opportunity to participate in decision-making, thereby enhancing their skills and allowing them to develop further in their subsequent empowerment. 
Phase four: prepares teamwork which includes: special mission teams, emergency problem solving teams and self-employment teams to qualify the individuals for the actual empowerment phase (Jalab and Al-Husseini, 2013). Phase five: it is called the administrative empowerment phase, which gives the employees the power to make decisions and to control how to do their work. In addition, it gives them the power to influence and change in the areas of various tourist resorts such as organizational objectives, structures and reward systems (Brewster, 2017).

\section{Administrative empowerment types}

1. Virtual empowerment: refers to the ability of the employees to give their opinion and to clarify their point of view regarding their work and activities. It is mainly concerned with the participation in the process of decision-making which is regarded as the essential component of the virtual empowerment process (Al-Saadi, 2006).

2. Behavioral Empowerment: refers to the ability of employees to work in a group to solve problems, and to present the recommendation for solving the problems. It also provides the employees with new skills that help them to improve their performance (Felemban, 2009).

3. Empowerment by results: includes the ability of employees to identify and resolve the causes of the problems, as well as, the ability to improve and change the working methods in such a way as to increase the effectiveness of the institution (Al-Tayeb, 2008 and AlKaabi, 2016).

\section{Challenges of administrative empowerment in resorts}

Many scholars (Brewster, 2017; Rahim, 2017; Collings et al., 2018), report the challenges that face resorts as follows;

1. Resistance to change by employees to implement administrative empowerment.

2. Lack of training programs to increase awareness of the importance of administrative empowerment.

3. The attitude of staff unwilling to change.

4. Feeling of insecurity between the management and the employees.

5. Personal qualities of managers, as traditional managers are often more interested in performing tasks than in the individual who performs the tasks.

6. The readiness of the workforce for the empowerment process. If not ready, it is the responsibility of the management and the resorts to prepare them. 


\section{The Effects of Administrative Empowerment on Employees Job Satisfaction in Five-star Resorts in Hurghada City}

\section{Job satisfaction}

\section{Job satisfaction concept}

Job satisfaction is defined by Abdelbaki (2004) as the emotional attitude of the individual employee towards his or her work. In the view of some scholars, job satisfaction is the degree of satisfaction of the needs of individuals in the light of work environment. This satisfaction is usually achieved through salaries provided, working conditions, the nature of supervision, the nature of the work itself, or recognition by others. On the other hand, job satisfaction is the attitude adopted by the individual towards his or her work. A person who is satisfied with work has positive attitudes towards work, whereas a person dissatisfied with his work has negative attitudes towards work (Al-Tayeb, 2008; Nassar, 2017).

\section{The importance of job satisfaction}

Job satisfaction is important not only for employees, but also for stakeholders, as it leads to increased productivity and reduced turnover ( $\mathrm{Lu}$ et al., 2016). The high level of job satisfaction confirms the effectiveness of the organization and the well-being of the staff. While the organization bears considerable costs, it does not experience a low level of job satisfaction among its staff. Job satisfaction affects the willingness of individuals to share their skills, knowledge and experience with others. Researchers have found that increased individual job satisfaction increases knowledge sharing, which in turn leads to improve employee performance (Zahid et al., 2017; Nassar, 2017). Many scholars (Lu et al., 2016; Lin et al., 2017; Zahid et al., 2017), report the importance of job satisfaction as below;

1. High job satisfaction leads to high ambition among employees in different institutions.

2. High level of job satisfaction leads to a low rate of absence of employees in an organization.

3. Highly satisfied employees are more satisfied with their leisure time, especially with their family, as well as a sort of satisfaction with their life in general.

4. Employees who are most satisfied with their work are less likely to have work accidents.

On the other hand, George and Zakkariya (2018) believe that dissatisfaction contributes to the delay of work and increases turnover and problems or complaints about working conditions. Felemban (2009) explains that job dissatisfaction for employees has negative effects on employees' motivation to work. Besides, there are many psychological and health problems for employees that lead to problems in the work environment, tension in staff-relationships and frequent absence. 
Additionally, job dissatisfaction leads to low level of productivity and deterioration in reputation. It is not only confined to the negative consequences of the work environment on the employee but also extended to the workplace and the employees' homes, causing tension in family relations and within the employee's relation to community. Thus, employees become more isolated and less interactive and communicative with the surrounding society (Burke et al., 2015).

\section{Elements of job satisfaction}

George and Zakkariya (2018) report that the most important elements to increase job satisfaction rates for employees are physical and moral stimulation, training and development, career empowerment, positive relationships and developing social relationships. Continuous training, the integration of staff in various initiatives for functional well-being, understanding and analyzing the needs of staff and establishing continuous communication between the senior management and the individuals are also among the factors that help achieve a high rate of job satisfaction. There are three main axes that are very important for raising the rates of job satisfaction in the workplaces. The first one is the workplace and the environment surrounding the employees. The second one is the social and psychological relations within the work (Kohli and Sharma, 2017). In addition to the importance of providing a positive working environment for employees in the government sector and adopting positive institutional values in all government organizations, the importance of job welfare programs and their positive impact in enhancing and improving employee productivity are highly emphasized (Kong et al., 2018).

Kruja et al. (2016) notes the importance of adopting healthy habits and practices in a work environment that play a critical role in increasing employee productivity and raising their levels of job satisfaction, which will positively affect the achievement of the strategic objectives of those organizations. Al-Saadi (2006) explains that there are specific criteria for employee satisfaction, including promotion, development, training and creation of a stimulating environment conducive to innovation. These standards, and others, must be measured with clear and specific performance indicators to ensure their modification and development if necessary.

The studies of Al-Kaabi (2016) and Nassar (2017) point out that one of the most important indicators of performance measurement in any side is the rate of decline of sick leave, which affect the ratio of turnover and high productivity. 


\section{The Effects of Administrative Empowerment on Employees Job Satisfaction in Five-star Resorts in Hurghada City}

Ashton (2018) adds the element of trust, which is a key element in the relationship between the employee's workplace and the employer. Trust consists of three dimensions: credibility, respect, and fairness (justice). Credibility means that managers communicate regularly with staff (Brewster, 2017). Respect includes providing staff with the necessary equipment, resources and training to carry out their work, as well as assessing good work and additional effort, including access to staff for making them partners in the activities of the foundation and fostering a spirit of cooperation between management and employee for creating a safe and healthy working environment (McPhail et al., 2015).

Equity means that there should be an equitable sharing of the economic success of the organization. There should be fair opportunities for recruitment and promotions without bias (Namasivayam et al., 2014). The nature of the work and the diversity of functions were important to the staff member, who felt that it was important when he was given powers to complete his work which increased his level of satisfaction at that moment. It is important to give highly qualified individuals certain powers and to provide them with some other elements of functional enrichment by giving them diverse and challenging tasks (Felemban, 2009, Tsaur et al., 2004).

\section{A conceptual framework of administrative empowerment in resort hotels}

This section constructs a conceptual framework, which explains administrative empowerment and its effect on job satisfaction of employees in resorts in Egypt. This conceptual framework is proposed to identify the study variables (see Figure 1). The study model is developed to include two variables. The first variable is the independent variable represented by administrative empowerment, which is measured through its dimensions of "delegation of authority, teamwork, training and development, motivation and independence in work, organizational structure and effective communication". The second variable is the dependent variable represented by job satisfaction which is measured through its dimensions of "feeling safe and providing incentives, nature of work, relationship with management, social status and community appreciation." 

S. Hassan. M
O. Ahmed.M
Abo-talib. S

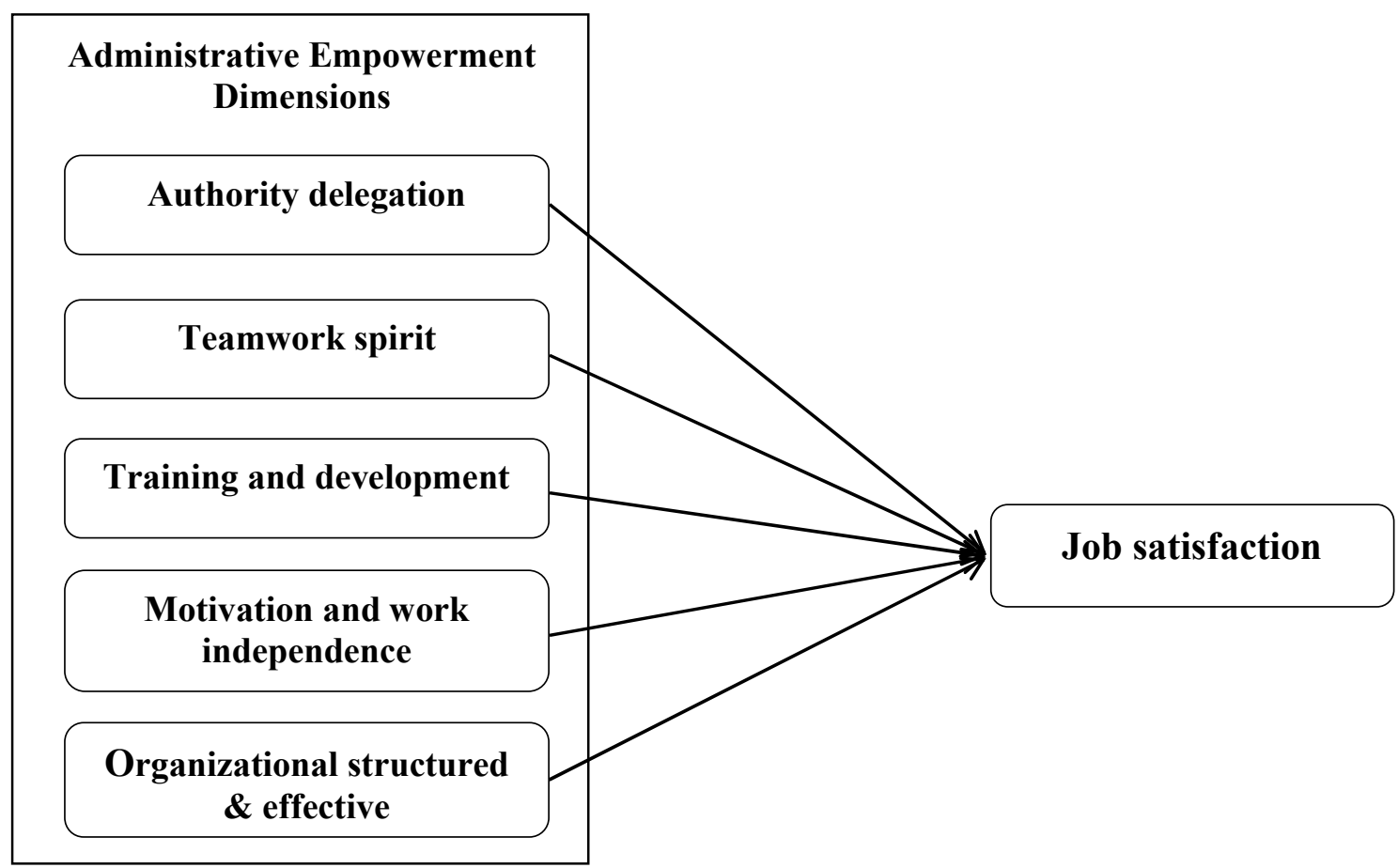

Fig. (1): A conceptual framework of administrative empowerment in resort hotels

\section{Methodology}

A quantitative approach is adopted to identify the extent of implementation of administrative empowerment of the employees and its effect on job satisfaction in five-star resorts in Hurghada City in Egypt. The data collection techniques consist of secondary and primary data. The secondary data includes books, thesis, journals and internet web sites related to empowerment and job satisfaction while the primary data utilizes a questionnaire instrument for data collection. The study population includes all employees in 23 resorts in Hurghada City in Egypt (EHA, 2018). Due to the lack of accurate statistical methods for determining the number of employees in these resort hotels, a convenient sample is used to target a sample of employees distributed by 30 employees in each resort hotels. 


\section{The Effects of Administrative Empowerment on Employees Job Satisfaction in Five-star Resorts in Hurghada City}

\section{Data collection}

To collect the main data, a questionnaire technique was used. The total number of distributed questionnaires was 690 copies. The final returned questionnaires were 500 copies with $72.4 \%$ response rate. Statistical Package for Social Sciences (SPSS, version 24) program was used for analyzing data. Data collection was done during 1 May 2018 until 25 July 2018.

\section{Measurement}

The questionnaire is divided into three sections. The first part consists of items about the respondents' demographic profiles (i.e. gender, age, job, education and experience). The second part consists of (20 items) of administrative empowerment dimensions. The final part consists of (20 items) of job satisfaction dimensions. A Likert scale is used for the administrative empowerment and job satisfaction dimensions, which includes five-point scale: (1) strongly disagree, (2) disagree, (3) neutral, (4) agree, (5) strongly agree.

\section{Research validity and reliability}

This study achieves validity through the following steps. Firstly, the questionnaire was written in Arabic language and then translated into English. Secondly, piloting was conducted among 10 professors in hospitality and tourism to ensure the initial questionnaire validity and to explore any potential misunderstanding among respondents related to the items wording or questionnaire length. Thirdly, a small pilot questionnaire was conducted with a convenient sample of employees to test any ambiguity in wording. After completion, the respondents were asked to identify any difficulties in completing or understanding the questions. They were also asked to make any changes, additions or suggestions to the questionnaire. On the other hand, Pallant (2007) confirms that if the Cronbach's Alpha is above 0.70, the scale of the sample will be reliable. The reliability of the current study was achieved thoroughly, as the researchers have conducted the Cronbach's Alpha coefficient that is 0.83 for administrative empowerment dimensions and 0.85 for job satisfaction dimensions. 


\section{Results and discussion}

\section{Demographic information of respondents}

The demographic attributes of the investigated the employees are shown in Table (2)

\begin{tabular}{|l|l|l|}
\multicolumn{4}{|c}{ Table (2): demographic data analysis } \\
\hline \multirow{4}{*}{ Variables } & Categories & Percentages \\
\hline \multirow{4}{*}{ Age } & Male & $83.2 \%$ \\
\cline { 2 - 3 } & Female & $16.8 \%$ \\
\hline \multirow{5}{*}{ Work experience } & from 20 to 25 years & $10.5 \%$ \\
\cline { 2 - 3 } & from 26 to 30 years & $18.5 \%$ \\
\cline { 2 - 3 } & From 31 to 40 years & $36.5 \%$ \\
\cline { 2 - 3 } & More than 41 years & $35.5 \%$ \\
\hline \multirow{5}{*}{ Educational qualifications } & Less than 5 years & $18.3 \%$ \\
\cline { 2 - 3 } & From 6 to 10 years & $50.4 \%$ \\
\cline { 2 - 3 } & More than 11 years & $31.3 \%$ \\
\cline { 2 - 3 } & Medium education & $29.7 \%$ \\
\cline { 2 - 3 } & Bachelor & $63 \%$ \\
\cline { 2 - 3 } & Master & $4.1 \%$ \\
\cline { 2 - 3 } & Doctor & $3.2 \%$ \\
\hline Functional level & employee & $31.8 \%$ \\
\cline { 2 - 3 } & supervisor & $26.9 \%$ \\
\cline { 2 - 3 } & Head of department & \\
\hline
\end{tabular}

Table (2) shows that most of the respondents were males, with a percentage of $(83.2 \%)$, indicating that most of the employees working at the resort are males. It was also noted that most respondents were in the category from 31 to 40 years with a percentage of $(36.5 \%)$. This result proves that the resort usually focuses on the youth category.

Regarding experience years, most of the respondents were in the middle category (from 6 to 10 years) representing (50.4\%) of the whole sample. This result indicates that the majority of employees in resorts are those of intermediate experience.

Table (2) also shows that most of the respondents were from Bachelor degree, with a percentage of $(63 \%)$. This result indicates that resorts are interested in recruiting employees with high education. Regarding the functional level, most of the respondents were from the employees level, as their percentage reached (41.8\%) from the total. 


\section{The Effects of Administrative Empowerment on Employees Job Satisfaction in Five-star Resorts in Hurghada City}

\section{Administrative empowerment dimensions}

\section{1- Authority of delegation}

The results of this statement are illustrated by Table (3).

Table (3): the respondent's views towards authority delegation

\begin{tabular}{|l|c|c|}
\hline \multicolumn{1}{|c|}{ Authority of delegation variables } & Mean & $\begin{array}{c}\text { Standard } \\
\text { deviation }\end{array}$ \\
\hline $\begin{array}{l}\text { The management delegates me with sufficient } \\
\text { powers to carry out my duties. }\end{array}$ & 3.88 & 0.42 \\
\hline $\begin{array}{l}\text { The management trusts in my abilities to perform } \\
\text { my tasks. }\end{array}$ & 4.00 & 0.33 \\
\hline $\begin{array}{l}\text { The management gives me more flexibility to } \\
\text { manage the way my tasks are carried out }\end{array}$ & 3.45 & 1.92 \\
\hline $\begin{array}{l}\text { The resort's system allows me to participate in } \\
\text { decision-making. }\end{array}$ & 4.06 & $\cdot .90$ \\
\hline $\begin{array}{l}\text { The opinions of the employees are taken into } \\
\text { consideration by the resort management. }\end{array}$ & 4.30 & 0.33 \\
\hline $\begin{array}{l}\text { Employees feel that their tasks are meaningful } \\
\text { and valuable in developing the resort. }\end{array}$ & 4.53 & 0.29 \\
\hline \multicolumn{1}{|c|}{ Statistics for all variables } & $\mathbf{4 . 0 3}$ & $\mathbf{0 . 5 3}$ \\
\hline
\end{tabular}

The previous Table (3) illustrates that the arithmetic means of the respondents' answers of the delegation authority and decision-making criteria ranged from 3.45 to 4.53 , but generally the total mean of the authority delegation and decision-making standard was 4.03 with a standard deviation 0.53. By comparing this mean with (Likert Scale), the value of the overall mean falls below the value (4), which is not agreed. This explains the limited scope of authority delegation in the five star resorts in Hurghada City. This is due to the fact that top management does not give the employees of the five star resorts more powers to make decisions without reference to them. This makes the employees feel that their jobs have no meaning and value because their opinions are not considered. These results are not in line with what the previous literature have pointed out in more than one place (Pelit et al., 2011) and (Al-Kaabi, 2016), as the delegation includes assigning employees tasks and giving them the authority to exercise these functions. This boosts the willingness of subordinates to bear responsibility of their performances and functions. 


\section{2- Teamwork}

The following Table (4) indicates that the arithmetic means of the respondents' answers of the teamwork criterion ranged from 2.86 to 4.86 , but generally the total mean of the teamwork dimension was (3.99) with a standard deviation 0.92. By comparing this mean with (Likert Scale), the value of the overall mean is between the values ( 3 neutral and 4 disagreed) and is very close to the value (4 disagreed). This proves that the perception of employees in the five star resorts in Hurghada city toward teamwork was weak. This result is because of the low participation and involvement of the staff at the resort in setting the objectives and policies of the resort, which consequently reduces the motivation of employees towards the institution. Although the previous literature (Gulab and Husseini, 2013) pointed out that the employees are ordered to accomplish the tasks through consulting and collaborating with coworkers and officials in organizational structure, the staff at the resort are not working and interacting with each other collaboratively. Consequently, the management is mainly concerned with encouraging and building teamwork for achieving the resort goal (Lee et al., 2015).

Table (4): the respondent's views towards teamwork

\begin{tabular}{|l|c|c|}
\hline \multicolumn{1}{|c|}{ Teamwork variables } & Mean & $\begin{array}{c}\text { Standard } \\
\text { deviation }\end{array}$ \\
\hline $\begin{array}{l}\text { Management encourages co-operative work and builds } \\
\text { a good teamwork. }\end{array}$ & 3.94 & $0.94 \cdot$ \\
\hline $\begin{array}{l}\text { My work is performed by one of my job mates in the } \\
\text { case of absence or sickness. }\end{array}$ & 2.85 & $0.96 \cdot$ \\
\hline $\begin{array}{l}\text { I confer with my Job mates concerning the tasks } \\
\text { entrusted to me. }\end{array}$ & 4.34 & 0.87 \\
\hline $\begin{array}{l}\text { My relations with the management officials are } \\
\text { cooperative ones. }\end{array}$ & 4.86 & $0.92 \cdot$ \\
\hline Statistics for all variables & $\mathbf{3 . 9 9}$ & $\mathbf{0 . 9 2}$ \\
\hline
\end{tabular}

\section{3- Training and development}

Table (5) shows the answers of the participants towards the statement of training and development. It also demonstrates the arithmetic means of the respondents' responses for the training and development phrases, which ranged from 4.71 to 3.81 . Therefore, the total mean of this dimension was 4.08 with a standard deviation 0.80 . This means that the degree of respondents' views was neutral concerning training and development dimension, as the employees of the resort do not have the complete autonomy in the selection and execution of the working methods. This result is due to 


\section{The Effects of Administrative Empowerment on Employees Job Satisfaction in Five-star Resorts in Hurghada City}

the weak desire of employees in five star resorts to develop their career as all employees have the same salaries and privileges, regardless of their participation in the professional training courses. The majority of respondents also admitted that the training programs offered by those resorts do not help them to develop their skills within their level of expectations. This result is not consistent with the previous literature, which stated that training is an ongoing process in the organization in order to constantly teach its staff new things and to help them apply what they have learned in the field of their work. Such training is so important for improving the quality of the offered products and services and for satisfying their users. The Success of organization in achieving its aims results from providing its employees with all the means of learning through training, experimentation, group learning and knowledge management (Namasivayam et al., 2014, Rahim, 2017). Training is directed towards developing the individual's abilities and skills of decision-making and taking the responsibility for the outcome of their decisions and actions (Lee et al., 2015).

Table (5): the respondent's views towards training and development

\begin{tabular}{|l|c|c|}
\hline \multicolumn{1}{|c|}{ Training and development variables } & Mean & $\begin{array}{c}\text { Standard } \\
\text { deviation }\end{array}$ \\
\hline The resort seeks to develop staff skills. & 4.71 & 1.05 \\
\hline The resort adopts a clear plan to identify training needs & 3.94 & 1.17 \\
\hline $\begin{array}{l}\text { The resort offers training programs to develop } \\
\text { employees' skills, which are commensurate with their } \\
\text { ambitions. }\end{array}$ & 3.88 & 1.16 \\
\hline $\begin{array}{l}\text { The resort's management strives to empower its } \\
\text { employees and to develop their professional and career } \\
\text { performance. }\end{array}$ & 4.27 & 1.07 \\
\hline $\begin{array}{l}\text { The resort encourages staff to share their experiences with } \\
\text { each other. }\end{array}$ & 3.81 & 1.10 \\
\hline $\begin{array}{l}\text { Staff has opportunities to learn and acquire new skills in } \\
\text { the field of work. }\end{array}$ & 3.89 & 1.11 \\
\hline Statistics for all variables & $\mathbf{4 . 0 8}$ & $\mathbf{0 . 8 0}$ \\
\hline
\end{tabular}

\section{4- Motivation and work independence}

Table (6) illustrates the arithmetic means of the respondents' answers for motivation and work independence dimension, which ranged from 4.77 to 3.25 , but generally the total mean related to motivation and work independence phrases was 4.14 with a standard deviation 0.43 . The value of the general mean falls below the value (4) which reflects the absence of motivation and work independence at the resort hotels.

This result is due to the fact that the management of the resort under the study does not encourage employees to express their opinions towards 
issues in their specialization or give them the ability to examine the problems they face during their work to find practical solutions. The management then does not have a full trust in the employees regarding achieving the required work, suggesting innovative solutions or finding creative solutions for the problems of their work-environment. This result is not consistent with the previous literature, which has affirmed that motivation has a vital role in the enhancement of relations between the organization and its employees in order to achieve the resort's objectives. Accordingly, motivation becomes the driving tool to know how to satisfy the needs of employees. Thus, if the management wants to increase the productivity and efficiency of its employees, it has to utilize a fair system of motivation and set objective incentives that are suitable for the employee's efforts at work. The organization has also to ensure that the system of promotion depends on employees' efficiency (Tsaur et al., 2004, Zahid et al., 2017).

Table (6): the respondent's views towards motivation and work independence

\begin{tabular}{|c|c|c|}
\hline Motivation and work independence variables & Mean & $\begin{array}{l}\text { Standard } \\
\text { deviation }\end{array}$ \\
\hline $\begin{array}{l}\text { I have a complete ability to solve the problems facing my } \\
\text { work and to find innovative solutions for them. }\end{array}$ & 4.17 & 0.66 \\
\hline $\begin{array}{l}\text { I follow the ways through which I do my work as long as } \\
\text { they are appropriate. }\end{array}$ & 3.25 & 0.32 \\
\hline $\begin{array}{l}\text { I have the opportunity to take any action that will ensure a } \\
\text { better quality of my work. }\end{array}$ & 4.37 & 0.22 \\
\hline $\begin{array}{l}\text { I am completely free to invent the appropriate method for } \\
\text { doing my work. }\end{array}$ & 4.77 & 0.55 \\
\hline Statistics for all variables & 4.14 & 0.43 \\
\hline
\end{tabular}

\section{5- Organizational structure and effective communication}

Table (7) demonstrates the arithmetic means of the respondents' answers for organizational structure and effective communication dimension, which ranged from 4.88 to 3.24 , but generally the total mean of the phrases of this dimension was 4.09 with a standard deviation 1.2), which reflects the absence of organizational structure and effective communication dimension in the five-star resorts in Hurghada City. 


\section{The Effects of Administrative Empowerment on Employees Job Satisfaction in Five-star Resorts in Hurghada City}

Table (7): the respondent's views towards organizational structure and effective communication

\begin{tabular}{|c|c|c|}
\hline $\begin{array}{c}\text { Organizational structure and effective communication } \\
\text { variables }\end{array}$ & Mean & $\begin{array}{l}\text { Standard } \\
\text { deviation }\end{array}$ \\
\hline $\begin{array}{l}\text { The management is interested in finding an effective means } \\
\text { of communication. }\end{array}$ & 3.75 & $0.89^{\circ}$ \\
\hline $\begin{array}{l}\text { Employees can reach the decision makers and explain their } \\
\text { opinions without difficulty. }\end{array}$ & 3.86 & 1.20 \\
\hline $\begin{array}{l}\text { There is an information system that provides the decision } \\
\text { makers with information quickly }\end{array}$ & 4.66 & 1.03 \\
\hline The organization's instructions and procedures are clear. & 4.20 & 1.70 \\
\hline $\begin{array}{l}\text { The organizational structure of the resort is devoid of } \\
\text { multiple managerial levels. }\end{array}$ & 4.88 & 1.55 \\
\hline $\begin{array}{l}\text { The resort's organizational structure is characterized by a } \\
\text { clear scope of supervision and authority distribution. }\end{array}$ & 3.24 & $0.92 \cdot$ \\
\hline Statistics for all variables & 4.09 & 1.20 \\
\hline
\end{tabular}

This result is because of the idea that the proper regulation creates the appropriate atmosphere in which the empowerment of employees and the total freedom they should have start to grow. The traditional or bureaucratic style by which the instructions and decisions are sequenced from top to bottom is no longer valid for empowerment process due to the inability of the staff to reach decision makers easily. This may also be a result of the multiplicity of managerial levels in the organizational structure, the existence of a weak and ineffective communication system between the administrative levels that does not provide information quickly, and the lack of clarity concerning the scope of supervision and the distribution of authority. On the other hand, previous literature have indicated that the organizational structure should be clear particularly in the distribution process of authorities and tasks, where staff can quickly communicate with decision-makers, without facing problems of multi administrative levels (Zahid et al., 2017).

\section{Job satisfaction}

\section{1- Feeling secure and providing incentives or rewards}

As indicated in Table (8), the arithmetic means of the respondents' estimates for the dimension's phrases ranged from $2.4-4.06$. In general the total mean of the phrases of this dimension is 3.18 with a standard deviation 0.67 . 
Table (8): the respondent's views towards a sense of security and the provision of incentives or rewards

\begin{tabular}{|c|c|c|}
\hline Feeling secure and providing incentives variables & Mean & $\begin{array}{l}\text { Standard } \\
\text { deviation }\end{array}$ \\
\hline $\begin{array}{l}\text { The resort's management increases my sense of belonging to } \\
\text { the resort. }\end{array}$ & 3.57 & .96 \\
\hline $\begin{array}{l}\text { The resort's management follows an administrative system that } \\
\text { increases my work motivation. }\end{array}$ & 4.19 & .96 \\
\hline $\begin{array}{l}\text { The hotel's system of incentives and promotions is } \\
\text { characterized by objectivity. }\end{array}$ & 4.60 & 1.20 \\
\hline My salary fits my work efforts & 3.57 & 1.15 \\
\hline $\begin{array}{l}\text { Staff competency is an important criterion for the system of } \\
\text { increasing salaries and promotions }\end{array}$ & 4.80 & 1.13 \\
\hline Statistics for all variables & 4.1 & 0.67 \\
\hline
\end{tabular}

This indicates that the overall average of strengthening the sense of security and providing incentives as a factor of job satisfaction is so weak at and barely appeared in five-star resorts in Hurghada. That's because resorts management neither supports the sense of full security towards the employees nor provides the employees with adequate salaries and incentives. This is demonstrated by the respondents' responses that reflect how the management does not follow an administrative system that increases the sense of security and job stability. The responses show the lack of objectivity in distributing incentives and promotions, as all employees have agreed that their salaries have decreased significantly in the recent period. This negatively affects the employee's sense of job satisfaction and professional affiliation. On contrary to these results, previous studies have highlighted the need to achieve job security for employees because it leads to increased productivity and reduced turnover (Lu et al., 2016).

\section{2- Environment of work}

It is clear from Table (9) that the arithmetic means of the respondents' estimates for this criterion ranged from $2.45-4.06$, but generally the average overall value is 4.2 with a standard deviation 1.03. This indicates that the area of work as an area of functional satisfaction rarely exists as emphasized through the attitude of the employees in five-star resorts in Hurghada City. 


\section{The Effects of Administrative Empowerment on Employees Job Satisfaction in Five-star Resorts in Hurghada City}

Table (9): the respondent's views towards the environment of work

\begin{tabular}{|l|c|c|}
\hline \multicolumn{1}{|c|}{ Environment of work variables } & Mean & $\begin{array}{c}\text { Standard } \\
\text { deviation }\end{array}$ \\
\hline $\begin{array}{l}\text { I am satisfied with the assessment of my direct manager to } \\
\text { my performance. }\end{array}$ & 4.42 & 1.09 \\
\hline $\begin{array}{l}\text { The work environment provides me with comfort and } \\
\text { reassurance state. }\end{array}$ & 4.22 & 0.91 \\
\hline The resort where I work is nearby my residential area. & 4.60 & 1.20 \\
\hline The work's procedures are clear. & 3.57 & 1.15 \\
\hline I like my work despite extra burdens. & 4.80 & 1.13 \\
\hline $\begin{array}{l}\text { The devices and equipment in my operation area are } \\
\text { available enough to enhance my performance. }\end{array}$ & 3.24 & $1 . \cdot^{\cdot \varepsilon}$ \\
\hline $\begin{array}{l}\text { The work conditions (i.e. ventilation, lighting, temperature, } \\
\text { noise, etc...) are appropriate. }\end{array}$ & 4.57 & 0.90 \\
\hline $\begin{array}{l}\text { Working in the resort provides me with a room for } \\
\text { innovation and creativity. }\end{array}$ & 4.19 & 0.86 \\
\hline \multicolumn{1}{|c|}{ Statistics for all variables } & $\mathbf{4 . 2}$ & $\mathbf{1 . 0 3}$ \\
\hline
\end{tabular}

This result is strongly related to the employee's dissatisfaction with the working conditions, which they deem unsuitable for the nature of the difficult jobs they practice and occupy. For doing these jobs, the employees are required to stand most of the time, working under physically difficult conditions. In addition, those employees lack family stability, since the majority of them are expatriates, which may reduce the job creativity opportunities as well as the endurance of the work's burdens whether original or additional. Although previous studies have stressed the importance of job satisfaction, as it affects individuals' desire to share their skills, knowledge, and experience with others, the results show the absence of appropriate work environment that enhances the employee's sense of job satisfaction. Researchers have found that increasing the individual's functional satisfaction increases the sharing of knowledge, which in turn leads to a better performance (Zahid et al., 2017; Nassar, 2017). In addition, George and Zakkariya (2018) point out that one of the most important factors for raising job satisfaction rates is the nature of the work and the conditions surrounding the work environment.

\section{3- Relationship with managers}

Table (10) indicates that the arithmetic means of the respondents' answers for the dimension's phrases ranged from $2.06-4.02$, but in general the arithmetic averages of the total phrases were 3.19 with a standard deviation 0.47 . This indicates that the general mean of the perceptions of the respondents towards the relationship of employees with their superiors, 
which is considered as one of the factors influencing job satisfaction, has been somewhat moderate or weak. This result is due to the poor relationship between the administrative levels of the resorts under study, because each level works in a different direction than the other, particularly the higher administrative levels. From the viewpoint of many subordinates, the centrality of senior management is a major cause for generating quarrels between the two parties and reducing the sense of public satisfaction towards the work within the institution. However, this result is not consistent with George and Zakkariya's (2018) views who stress the importance of the relationship between bosses and workers in the workplace, as it is one of the most important factors for increasing job satisfaction rates of employees. Ashton (2018) added that trust, which is an essential element in the relationship between the employee's workplace and the employer, consists of three dimensions: credibility, respect and fairness (justice).

Table (10): the respondent's views concerning their relationship with managers

\begin{tabular}{|c|c|c|}
\hline Relationship with managers variables & Mean & $\begin{array}{l}\text { Standard } \\
\text { deviation }\end{array}$ \\
\hline $\begin{array}{l}\text { My superiors help me show more commitment to } \\
\text { work laws and regulations. }\end{array}$ & 3.88 & 0.53 \\
\hline $\begin{array}{l}\text { My superiors help me solve the problems that I face } \\
\text { in my job. }\end{array}$ & 3.09 & 0.33 \\
\hline $\begin{array}{lrrrr}\begin{array}{l}\text { My superiors } \\
\text { recommendations } \\
\text { development. }\end{array} & \begin{array}{r}\text { accept my } \\
\text { regarding }\end{array} & \begin{array}{c}\text { suggestions } \\
\text { career }\end{array} & \begin{array}{r}\text { and } \\
\text { level }\end{array} \\
\end{array}$ & 3.45 & .021 \\
\hline $\begin{array}{l}\text { There are quarrels between my work superiors and } \\
\text { me. }\end{array}$ & 2.06 & .80 \\
\hline My superiors treat me with respect and appreciation. & 2.30 & 0.34 \\
\hline $\begin{array}{l}\text { My superiors appreciate my efforts while performing } \\
\text { my duties. }\end{array}$ & 3.58 & 0.80 \\
\hline $\begin{array}{l}\text { My superiors sometimes care about my personal } \\
\text { circumstances. }\end{array}$ & 4.02 & 0.62 \\
\hline Statistics for all variables & 3.19 & 0.47 \\
\hline
\end{tabular}

\section{4- Social status and community appreciation}

Table (11) indicates that the arithmetic means of the respondents' answers for the phrases of this criterion ranged from 4.90 to 2.60. Generally, the value of total mean was 3.76 with a standard deviation 1.09 , which indicates that the general mean of the perceptions of employees in five-star resort in Hurghada City regarding the social status, as one of the effective variable on job satisfaction, is moderate or weak. This result is due to that the employees' belief that community looks at them with a degrading and an 


\section{The Effects of Administrative Empowerment on Employees Job Satisfaction in Five-star Resorts in Hurghada City}

insulting eye. This is reflected in the answers of many employees, whom asserted that if they have another job in another field, they will quit immediately without hesitation. This is considered one of the main reasons of the dissatisfaction of employees especially kitchen and restaurant employees. This result is in line with previous literature (Al Kaabi, 2016; Nassar, 2017).

Table (11): the respondent's views towards social status and community appreciation

\begin{tabular}{|c|c|c|}
\hline $\begin{array}{c}\text { Social status and community appreciation } \\
\text { variables }\end{array}$ & Mean & $\begin{array}{l}\text { Standard } \\
\text { deviation }\end{array}$ \\
\hline $\begin{array}{l}\text { Community does not consider working in the field of } \\
\text { resorts as an undervalued and insulting work. }\end{array}$ & 3.57 & 0.86 \\
\hline $\begin{array}{l}\text { My job contributes to improving the social position I } \\
\text { desired. }\end{array}$ & 4.15 & 1.19 \\
\hline $\begin{array}{l}\text { My family members appreciate my job in the field of } \\
\text { resorts. }\end{array}$ & 2.60 & 1.20 \\
\hline $\begin{array}{l}\text { I will continue working in the field of resorts in the } \\
\text { future. }\end{array}$ & 3.57 & 1.01 \\
\hline The media frequently sheds light on resorts staff. & 4.90 & 1.19 \\
\hline Statistics for all variables & 3.76 & 1.09 \\
\hline
\end{tabular}

\section{Hypotheses testing}

\section{1-Test of the first hypothesis}

- There are no statistically significant differences of demographic variables of administrative empowerment of employees in five-star resort hotels in Hurghada City.

Table (12): Analysis of the single variation (one-way ANOVA) of demographic variables concerning the employees' empowerment level

\begin{tabular}{|c|c|c|c|c|c|c|}
\hline Variables & $\begin{array}{c}\text { Variation } \\
\text { source }\end{array}$ & $\begin{array}{c}\text { Degrees } \\
\text { of } \\
\text { freedom }\end{array}$ & $\begin{array}{c}\text { Total } \\
\text { squares }\end{array}$ & $\begin{array}{l}\text { Average } \\
\text { squares }\end{array}$ & $\begin{array}{l}\text { Value } \\
\text { (F) }\end{array}$ & $\begin{array}{c}\text { Significant } \\
\text { level }\end{array}$ \\
\hline \multirow[t]{2}{*}{ Gender } & Between groups & 32 & 61.13 & 1.91 & \multirow[b]{2}{*}{25.84} & \multirow[b]{2}{*}{$0.000 *$} \\
\hline & Within groups & 368 & 23.58 & 0.07 & & \\
\hline \multirow[t]{2}{*}{ Age } & Between groups & 32 & 370.41 & 11.57 & \multirow[b]{2}{*}{65.55} & \multirow[b]{2}{*}{$0.000^{*}$} \\
\hline & Within groups & 368 & 56.32 & 0.17 & & \\
\hline \multirow{2}{*}{$\begin{array}{l}\text { Scientific } \\
\text { qualificati } \\
\text { on }\end{array}$} & Between groups & 32 & 127.15 & 3.97 & \multirow[b]{2}{*}{22.39} & \multirow[b]{2}{*}{$0.000^{*}$} \\
\hline & Within groups & 368 & 56.61 & 0.17 & & \\
\hline \multirow{2}{*}{$\begin{array}{c}\text { Functiona } \\
\text { l } \\
\text { experienc } \\
\text { e }\end{array}$} & Between groups & 32 & 25.85 & 0.80 & \multirow[b]{2}{*}{0.862} & \multirow[b]{2}{*}{$0.000 *$} \\
\hline & Within groups & 368 & 299.16 & 0.93 & & \\
\hline \multirow[t]{2}{*}{$\begin{array}{c}\text { Career } \\
\text { level }\end{array}$} & Between groups & 32 & 280.07 & 8.75 & \multirow[b]{2}{*}{19.94} & \multirow[b]{2}{*}{$0.000 *$} \\
\hline & Within groups & 368 & 140 & 0.43 & & \\
\hline
\end{tabular}

* Statistically significant at 0.05 
Table (12) shows that the calculated (F) value is (25.84) at a significant level $(0.05)$ and degrees of freedom $(32,368)$ which indicates that there are significant differences between respondents toward the level of employees empowerment due to the gender variable. This result is confirmed by the significant level of $(F)$ which equals $(0.0000)$ whereas it is less than (0.05) and this is the level used by this study. It also shows that (65.55) is the value of the age variable, and is (22.39) in respect to the educational qualification, and (0.686) for the experience variable, and (19.94) for the career level variable.

The previous data analysis shows that null hypothesis was rejected and the alternative hypothesis was accepted, which states that there are statistically significant differences in respondents' attitudes towards the level of administrative empowerment due to demographic variables (gender, age, scientific qualification, level of employment).

\section{2-Second hypothesis test}

- There are no statistically significant effects of administrative empowerment of employees on job satisfaction in five-star resort hotels in Hurghada City.

Table (13) shows the results of multiple regression analysis for measuring the impact of administrative empowerment dimensions on the employees' job satisfaction from the view of the respondents.

\section{Table (13): Simple regression analysis}

\begin{tabular}{|c|c|c|c|c|c|c|}
\hline \multirow{3}{*}{\multicolumn{2}{|c|}{$\begin{array}{l}\text { Correlation coefficient } \mathbf{R} \\
\text { Determination coefficient } \\
\mathbf{R}^{2}\end{array}$}} & \multicolumn{5}{|l|}{0.702} \\
\hline & & \multicolumn{5}{|l|}{0.655} \\
\hline & \multicolumn{6}{|c|}{ ANOVA } \\
\hline & $\begin{array}{c}\text { Total } \\
\text { Squares }\end{array}$ & $\begin{array}{l}\text { Degrees } \\
\text { of } \\
\text { freedom }\end{array}$ & $\begin{array}{l}\text { Average } \\
\text { Squares }\end{array}$ & $\mathbf{F}$ & & ignificant \\
\hline $\begin{array}{l}\text { Between } \\
\text { groups }\end{array}$ & 16.714 & 1 & 6.608 & \multirow{2}{*}{0.485} & \multirow{2}{*}{\multicolumn{2}{|c|}{0.000}} \\
\hline \multirow[t]{2}{*}{$\begin{array}{l}\text { Within } \\
\text { groups }\end{array}$} & 0.786 & 54 & 0.402 & & & \\
\hline & \multicolumn{3}{|c|}{ (F) value $0.485=$} & \multicolumn{3}{|c|}{ (F) Significant 0.000 } \\
\hline Variable & B & SE b & \multicolumn{2}{|c|}{ ( $\beta$ )Beta } & (T) & $\begin{array}{c}(\mathbf{T}) \\
\text { Significant }\end{array}$ \\
\hline $\begin{array}{l}\text { Empowering } \\
\text { management }\end{array}$ & 1.795 & 0.269 & \multicolumn{2}{|c|}{0.565} & 0.573 & 0.000 \\
\hline
\end{tabular}




\section{The Effects of Administrative Empowerment on Employees Job Satisfaction in Five-star Resorts in Hurghada City}

Analysis of the results shown in the previous table shows the following:

- Test the significant of the regression coefficients

The ( $\mathrm{T})$ value of the independent variable "administrative empowerment" was $(0.573)$ with a significant degree $(0.000)$ at a significant level (0.05). Therefore, the independent variable, administrative empowerment, has an impact on the dependent variable (i.e. job satisfaction).

- Relationship strength test

The value of the determination coefficient $\left(\mathrm{R}^{2}\right)$ was $(0.655)$. This means that there is a strong impact of the independent variable on the dependent variable, which indicates that $(65 \%)$ of the changes that occur in the dependent variable "Job satisfaction" are due to the changes that occur within the independent variable.

\section{- Total Variance Analysis}

The calculated $(\mathrm{F})$ value was $(0.485)$ at significant level $(0.05)$ and degrees of freedom (1.54). The results indicate that the level of (F) at $(0.000)$ level is less than (0.05), which demonstrates the existence of significant differences.

Based on the foregoing of the results of the simple regression analysis, the null hypothesis is rejected after recognizing the significant effect of the administrative empowerment variables on job satisfaction. Consequently, the alternative hypothesis is accepted. Such hypothesis shows a statically significant effect of the administrative empowerment on the rate of job satisfaction at five star resorts in Hurghada City at a significant level (0.05).

\section{Conclusion}

The main objective of this study is to identify the process of empowering employees in the five star resorts of Hurghada, as well as, the impact of this empowerment on job satisfaction. The study shows whether there are statistically significant differences in the attitude of respondents about empowering the employees in the resorts under study and the level of job satisfaction related to demographic variables. In order to achieve the aim of this study, the theoretical framework has been reviewed to determine the variables influencing the problem of the study, followed by drafting it. Afterwards, a questionnaire is designed to be distributed to the 500 employees of the resorts under study.

The results of the study are shown according to the sequence of its objectives and hypotheses as follows:

- The study demonstrated that the degree of empowerment of employees in the resorts was moderate or weak.

- It also displayed that the overall level of job satisfaction for the employees in five star resorts in Hurghada was moderate or weak. 
The study pointed out a statistically significant effect of administrative empowerment variables on the job satisfaction of employees in the five-star resorts of Hurghada.

- The study showed that there are statistically significant differences in the attitudes of respondents concerning the degree of administrative empowerment in relation to demographic variables (e.g. gender, age, scientific qualification, job level, experience).

\section{Recommendations}

The finding of the present study stated that managers should delegate more authority to employees to enhance their confidence and to increase their performance effectively. The resort managers have to provide a healthy organizational atmosphere that encourages to practice empowerment, and to set some strategies and mechanisms that contribute to empowering and training employees on modern decision-making techniques. This helps increase the rate of job satisfaction on the other hand. In light of the foregoing, the study recommends the following:

1- To leave details to the employees to act on them, after the managers have formulated the vision and the mission, set the objectives of the main institution, and developed feelings of trust, appreciation, commitment and membership of the workers.

2- To adopt an appropriate incentive system, by which workers must receive the necessary and adequate income and status. The employees should also feel a sense of appreciation displayed by the organization for their exceptional and distinct efforts in the achievement of tasks required of them.

3- To provide the necessary information to enable workers to make effective decisions, bearing in mind that they already possess information about the nature of their jobs and the circumstances surrounding them, as well as about the resort and its objectives.

4- To have confidence in the dedication of employees and their enthusiasm for work. The employees must feel confident. They should be aware of the possibility of committing mistakes in certain situations, since those who infallible are only those who do not actually work.

5- To pay attention to ongoing training programs to strengthen the skills of empowerment and to measure its return periodically to determine its impact on the practical practices of the employees.

6- To increase the opportunity for staff to learn, and to have career progression, recognition and appreciation, this will result in the continuous improvement of the activities of the labor services. 
7- To make use of successful empowerment experiences applying them to resorts to ensure the occurrence of positive changes in a continuous and integrated manner.

8- To train officials in resorts on the methods which are supportive to empowerment, including team effort, participation in the development of the skills of the employees in solving problems creatively, achieving cooperation and coordination, and providing a management characterized by openness and transparency.

9- To focus more on delegation of authority and staff training, as they have a clear impact on enhancing the level of job satisfaction of employees.

10-Resort administration should give greater attention to the human element by motivating and involving workers in decision-making, as it is an important element in achieving the foundation's goals and increasing the job satisfaction of the employees.

11-Resort administration should pay great attention towards the employees, by providing suitable salaries, improving the relationship between the superiors and the subordinates, and identifying the requirements and expectations of the superiors.

12- To provide an appropriate organizational atmosphere in an enterprise that is characterized by security due to its positive impact on job satisfaction of the employees.

13- To spread team spirit, to show enthusiasm and optimism, and to allow the subordinates to participate in the achievement of the common goals.

\section{Further research}

Because of the richness of the concepts of administrative empowerment and job satisfaction and their influence and impact on more organizational factors and variables, this study limits its scope on the impact of administrative empowerment on job satisfaction. It recommends the necessity of linking administrative empowerment with other organizational variables such as organizational loyalty, organizational justice, productivity enhancement and performance improvement. Furthermore, it highly recommends conduct of researches and field studies in the area of administrative empowerment and job satisfaction in other hotel types in Egypt. 


\section{References}

Abdelbaki, S.M., (2004), Job Satisfaction in Organizations, University House Publishing, Alexandria.

Abualoush, S.H., Obeidat, A.M., Tarhini, A., Masa'deh, R.E. and Al-Badi, A., (2018). The role of employees' empowerment as an intermediary variable between knowledge management and information systems on employees' performance. VINE Journal of Information and Knowledge Management Systems, 48(2), pp.217-237.

Ajlouni, M.D.I.A., (2013). The Relationship between Knowledge Management and Empowerment of Administrative on Organizational Trust. Eur. J. Bus. Manage, 5, pp.230-237.

Al-Dmour, R., Yassine, O. and Masa'deh, R.E., (2018). A Review of Literature on the Associations among Employee Empowerment, Work Engagement and Employee Performance. Modern Applied Science, 12(11).

Al-Kaabi, H.S., (2016). The Role of Administrative Empowerment in Promoting Organizational Innovation, Al-Muthanna Journal of Administrative and Economic Sciences, 6 (1), pp.24-40.

Al-Saadi, M. Y., (2006). Measuring the Business's Willingness to Work with an Empowerment Strategy. $1^{\text {st }}$ ed., Al-Warraq Publishing, Amman, Jordan, p.761.

Al-Tayeb, E.M., (2008). The Impact of Organizational Climate on Job Satisfaction", Unpublished Master Thesis, Faculty of Commerce, Islamic University, Gaza.

Ashton, A.S., (2018). How human resources management best practice influence employee satisfaction and job retention in the Thai hotel industry. Journal of Human Resources in Hospitality \& Tourism, 17(2), pp.175-199.

Bailey, C., Mankin, D., Kelliher, C. and Garavan, T., (2018). Strategic human resource management. Oxford University Press.

Bratton, J. and Gold, J., (2017). Human resource management: theory and practice. Palgrave.

Brewster, C., (2017). The integration of human resource management and corporate strategy. In Policy and practice in European human resource management. Routledge, pp. 22-35.

Burke, R.J., Koyuncu, M., Wolpin, J., Yirik, S. and Koyuncu, K., (2015). Organizational Empowerment Practices, Psychological Empowerment and Work Outcomes among Frontline Service Employees in Five-Star Turkish Hotels. Effective Executive, 18(1), p.42.

Collings, D.G., Wood, G.T. and Szamosi, L.T., (2018). Human resource management: A critical approach. In Human Resource Management. Routledge, pp. 1-23

EHA, (2018). Egyptian hotel association, URL:http://www.egyptianhotels.org/Hotelssearch.aspx?City $=$ CAIRO\&Type $=0002 \&$ Category $=* * * * * \&$ hotel $=$ All 


\section{The Effects of Administrative Empowerment on Employees Job Satisfaction in Five-star Resorts in Hurghada City}

Felemban, I.F.N., (2009). Job Satisfaction and its Relation to Organizational Commitment", unpublished Master Thesis, Faculty of Education, Umm AlQura University, Makkah, Saudi Arabia, p.50.

George, E. and Zakkariya, K.A., (2018). Psychological Empowerment and Job Satisfaction in the Banking Sector. Springer.

Jalab, I.D. and Al-Husseini, K.K.Z., (2013). Administrative of Empowerment and Integration, $1^{\text {st }}$ ed., Dar Safa for Publishing and Distribution.

Kohli, A. and Sharma, A., (2017). An Analysis of Employee Empowerment And Job Satisfaction: A Review. Management Dynamics, 17(1).

Kong, H., Jiang, X., Chan, W. and Zhou, X., (2018). Job satisfaction research in the field of hospitality and tourism. International Journal of Contemporary Hospitality Management, (just-accepted), pp.00-00.

Kruja, D., Ha, H., Drishti, E. and Oelfke, T., (2016). Empowerment in the hospitality industry in the United States. Journal of Hospitality Marketing \& Management, 25(1), pp.25-48.

Lee, J.S., Back, K.J. and Chan, E.S., (2015). Quality of work life and job satisfaction among frontline hotel employees: A self-determination and need satisfaction theory approach. International Journal of Contemporary Hospitality Management, 27(5), pp.768-789.

Lin, M., Wu, X. and Ling, Q., (2017). Assessing the effectiveness of empowerment on service quality: A multi-level study of Chinese tourism firms. Tourism Management, 61, pp.411-425.

Lu, L., Lu, A.C.C., Gursoy, D. and Neale, N.R., (2016). Work engagement, job satisfaction, and turnover intentions: A comparison between supervisors and line-level employees. International Journal of Contemporary Hospitality Management, 28(4), pp.737-761.

McPhail, R., Patiar, A., Herington, C., Creed, P. and Davidson, M., (2015). Development and initial validation of a hospitality employees' job satisfaction index: Evidence from Australia. International Journal of Contemporary Hospitality Management, 27(8), pp.1814-1838.

Namasivayam, K., Guchait, P. and Lei, P., (2014). The influence of leader empowering behaviors and employee psychological empowerment on customer satisfaction. International Journal of Contemporary Hospitality Management, 26(1), pp.69-84.

Nassar, M.A., (2017). Psychological empowerment and organizational change among hotel employees in Egypt. Research in Hospitality Management, 7(2), pp.91-98.

Pallant, J. (2007), SPSS survival manual: A step by step guide to data analysis using SPSS for windows, $3^{\text {rd }}$ ed., New York, McGraw Hill, Open University Press.

Pelit, E., Öztürk, Y. and Arslantürk, Y., (2011). The effects of employee empowerment on employee job satisfaction: A study on hotels in Turkey. International Journal of Contemporary Hospitality Management, 23(6), pp.784-802.

Rahim, M.A., (2017). Managing conflict in organizations. Routledge.

Tsaur, S.H., Chang, H.M. and Wu, C.S., (2004). Promoting service quality with 


\section{S. Hassan. M O. Ahmed. M Abo-talib. S}

employee empowerment in tourist hotels: The role of service behavior. Asia Pacific Management Review, 9(3), pp.435-461.

Zahid, M., Shaikh, T. and Zehra, S.Z., (2017). Impact of Organizational Culture on the Pakistani Hotels Workforce's Job Satisfaction: Qualitative Report.

\section{الملخص العزبي}

\section{الادارة بالتمكين وأثرها علي الرضا الوظيفي للعاملين بالمنتجعات الخمس نجوم بمدينة الغزدة التونة}

تحتل الإدارة بالتمكين أهمية بالغة للعاملين نظر الكونها من المفاهيم المعاصرة التي ترتقي بالعنصر

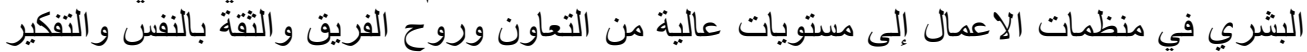

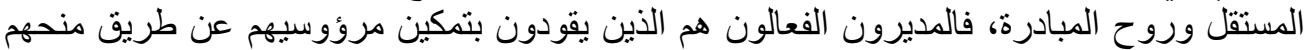

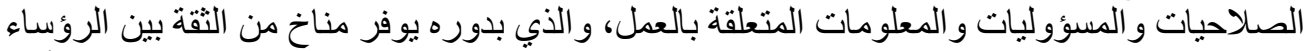

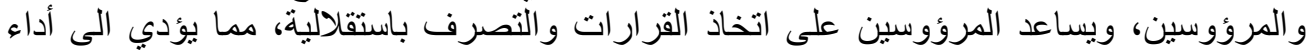

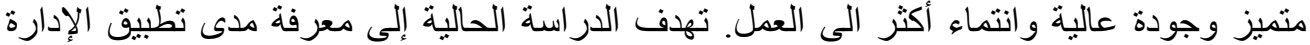

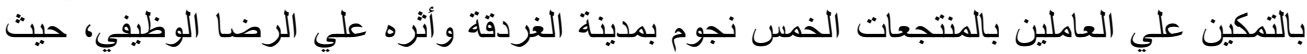

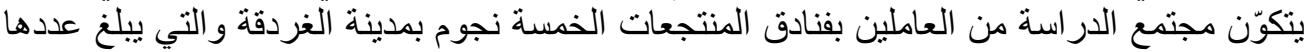

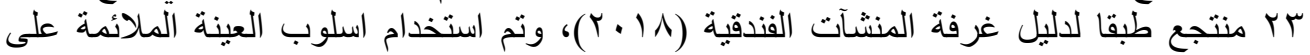

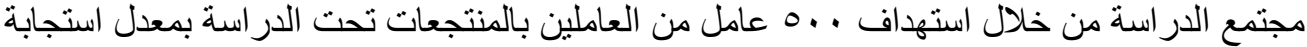

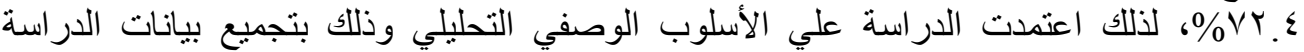

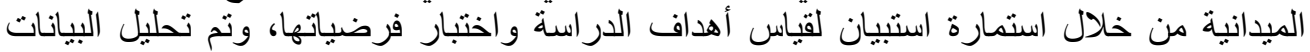

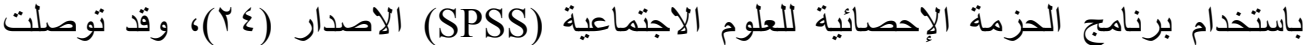

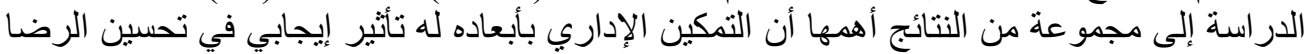

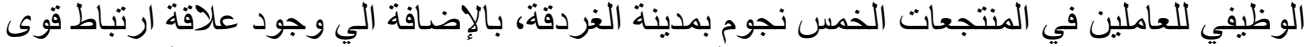

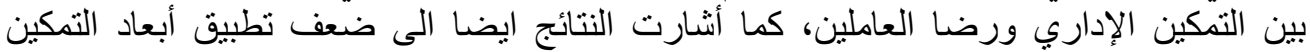

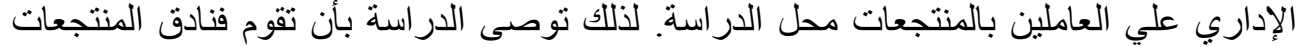

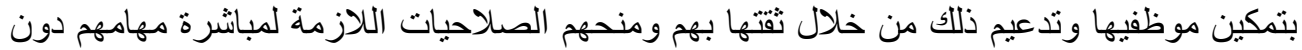

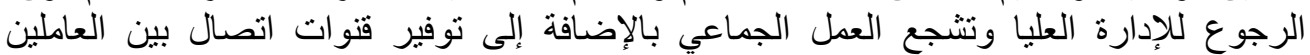
و المستويات الإدارية العليا. ومنه ساهمت هذه الدراسة في التعرف على فلى مفهوم التمكين الإداري

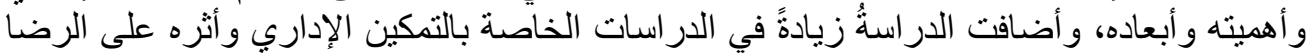

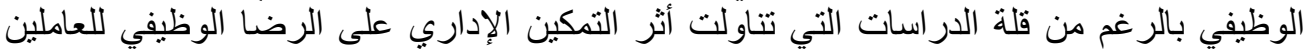

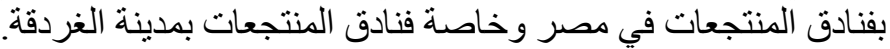

الكلمات الدالة: الإدارة بالتمكين، الرضا الوظيفي، العاملين، فنادق المنتجعات، الغردقة 